NOTA PRÉVIA*

\title{
Avaliação Qualitativa do Sistema de Vigilância Epidemiológica do Ceará
}

\author{
Qualitative Evaluation of Ceará's Epidemiological \\ Surveillance System
}

\section{Ricardo José Soares Pontes}

Departamento de Saúde Comunitária / Universidade Federal do Ceará

\section{Márcia Maria Tavares Machado}

Departamento de Saúde Comunitária / Universidade Federal do Ceará

\section{Lígia Regina S. Kerr Pontes}

Departamento de Saúde Comunitária / Universidade Federal do Ceará

\section{Correspondência para:}

Ricardo José Soares Pontes

Rua Professor Costa Mendes, 1608 - 5o andar

CEP: 60.431-970

Fortaleza-CE

E-mail: rjpontes@fortalnet.com.br

\section{Apoio financeiro:}

Pesquisa componente do Programa de Desenvolvimento Científico do Centro Nacional de Epidemiologia - Fundação Nacional de Saúde. Financiada pelo Projeto de Estruturação do Sistema Nacional de Vigilância em Saúde do SUS (VIGISUS). 


\section{Summary}

\section{Background}

In 1976 the Ministry of Health started the implementation of the National Epidemiological Surveillance System. The implantation of the Brazilian Unified Health System (1988) proposed a new model of management, represented by decentralization and municipalization. After 1998, the structuring of the National System for Health Surveillance was proposed. The objective of this study is to evaluate the Epidemiological Surveillance System of Ceará State Health Department, at the central, regional and municipal levels, in the context of institutional development.

\section{Material and methods}

The study was carried out in the Ceará State Health Department in 2001. A qualitative research methodology was used which included focus group and non structured open individual interviews. A total of 32 health professionals who work in the epidemiological surveillance at the central, regional and municipal levels participated (intentional sample). They were considered key-informants and 13 participated in focus groups, and 19 were interviewed. Interviews were taped, transcribed and analysed using the "Ethnograph 4.0" program. The following analytic categories were used: surveillance structure, data analyses, human resources, integration activities, surveillance decentralization, conceptualization and health surveillance structure process.

\section{Results}

Advances in operational infrastructure, in computerization, data transfer, and availability of human resources dedicated to epidemiological surveillance were observed at the central, regional and municipal levels in the state of Ceará. Due to decentralization, the municipalities were incorporated into the epidemiological surveillance system, mainly in the collection and transfer of information. Some activities had a greater institutional development, such as epidemiological notification and investigation. Data analysis continues to be a serious bottleneck in all levels of the system. Another bottleneck is human resources rotativity at the local level. The present conceptualization of health surveillance implies the integration of various types of surveillance. The organization of environmental surveillance suffers from limited financial assistance and the lack of qualified professionals with technical competence to act in the field. The incorporation of new areas of surveillance did not promote the creation of a more inclusive or integrated health surveillance.

\section{Conclusions}

Due to municipalization, an important operational development occurred in the epidemiological surveillance system in the state of Ceará. However, qualitative advancement in its most important activities, analysis of data, and the creation of a broader health surveillance, was not achieved. There remains a necessity for team capacity building and implementation of careers for permanent and stable technicians at the municipalities.

\section{Key words}

Epidemiological Surveillance; Evaluation; Service Evaluation; Qualitative Methodology. 


\section{Resumo}

\section{Delineamento do problema}

O Ministério da Saúde iniciou a implementação do Sistema Nacional de Vigilância Epidemiológica em 1976. A implantação do SUS (1988) propiciou um novo modelo de gestão, representado pela descentralização e municipalização. A partir de 1998, foi proposta a estruturação do Sistema Nacional de Vigilância em Saúde. Objetivase avaliar o Sistema de Vigilância Epidemiológica da Secretaria de Saúde do Ceará, nos níveis central, regional e municipal, nesse contexto de desenvolvimento institureional.

\section{Material e métodos}

O estudo foi realizado na Secretaria de Saúde do Ceará, em 2001. Utilizou-se metodologia de pesquisa qualitativa, com a realização de grupo focal e entrevistas individuais abertas não estruturadas. Participaram 32 profissionais de saúde (amostra intencional) que atuam na vigilância epidemiológica a nível central, nas microregiões e municípios do estado (13 no grupo focal e 19 através de entrevistas), considerados "informantes-chave". As entrevistas foram gravadas, transcritas e analisadas utilizando o programa "The Ethnograph 4.0". As categorias analíticas utilizadas foram: estruturação da vigilância, análise de dados, recursos humanos, integração das ações, descentralização da vigilância, concepção e estruturação da vigilância em saúde.

\section{Resultados}

Observou-se um avanço na infraestrutura operacional, na informatização, fluxo de dados e disponibilidade de recursos humanos vinculados à vigilância epidemiológica no nível central estadual, nas regionais e nos municípios do Ceará. Fruto da descentralização, os municípios foram incorporados ao Sistema de Vigilância Epidemiológica, principalmente na coleta e fluxo de informação. Algumas atividades tiveram um maior desenvolvimento institucional, como a notificação e a investigação epidemiológica. A análise de dados continua sendo um importante ponto de estrangulamento em todos os níveis do sistema. Outro ponto de estrangulamento se refere aos recursos humanos, submetidos a alta rotatividade no nível local. A concepção de vigilância à saúde presente se vincula à integração das várias vigilâncias. A estruturação da vigilância ambiental sofre limitações de financiamento e inexistência de profissionais com competência técnica para atuar na área. A incorporação de novas áreas de atuação na vigilância não promoveu a constituição de uma vigilância à saúde mais abrangente e integrada.

\section{Conclusões}

Ocorreu um importante desenvolvimento operacional da vigilância epidemiológica no Ceará, decorrente da municipalização.Entretanto, não se logrou um avanço qualitativo em sua atividade nuclear mais importante, a análise de dados, nem na constituição de uma área de vigilância à saúde mais abrangente. Permanece a necessidade de capacitação das equipes e a implementação de carreiras com técnicos permanentes e estáveis nos municípios.

\section{Palauras-chave}

Vigilância Epidemiológica; Avaliação; Avaliação de Serviço; Metodologia Qualitativa. 